\title{
PENINGKATAN MINAT BACA DI KALANGAN ANAK USIA DINI DI SEKOLAH ALTERNATIF ANAK JALANAN (SAAJA)
}

\author{
Anis Mariska ${ }^{1}$, Anisyah Adiningsih ${ }^{2}$, Claudya Anindyta ${ }^{3}$, \\ Pupung Dianing Ratri ${ }^{4}$, Yunia Puspita Anggraini ${ }^{5}$, Dini Safitri ${ }^{6}$ \\ 1,2,3,4,5,6 Universitas Negeri Jakarta \\ Email: dinisafitri@unj.ac.id
}

\begin{abstract}
Indonesia there have been many formal schools established in terms of developing children's education at an early age, so that the quality and quality of children in big cities is good. However, formal schools require considerable costs so that they are still difficult to reach by underprivileged families. Concern for underprivileged families inspired the establishment of alternative schools in order to reach education at an early age as an example of which in SAAJA these children experienced a number of problems including lack of awareness of reading interest in each individual, limited human resources, and lack of facilities, especially children's reading books. The purpose of this service activity is to foster reading interest in early childhood at SAAJA. The method used is the Storytelling Method and the Learning While Playing Method. As a result of this activity, participants actively read children's books in addition they are able to sharpen their memory to remember what they have told.
\end{abstract}

Keywords: Reading interest, Early Childhood, Storytelling

\begin{abstract}
Abstrak, Di kota-kota besar di Indonesia telah banyak berdiri sekolah formal dalam hal pengembangan pendidikan anak pada usia dini, Sehingga mutu dan kualitas anak-anak dikota besar sudah bagus. Namun, sekolah formal memerlukan biaya yang cukup besar sehingga masih sulit dijangkau oleh keluarga prasejahtera.Kepedulian terhadap keluarga prasejahteramemberikan inspirasi untukmendirikan sekolah alternatif demi menjangkau pendidikan pada usia dini sebagai contoh salah satunya adalah di SAAJA anak-anak tersebut mengalami sejumlah permasalahan diantaranya yaitu kurangnya kesadaran minat baca pada masing-masing individu, keterbatasan sumber daya manusia, dan minimnya fasilitas, terutama bukubuku bacaan anak. Tujuan kegiatan pengabdian ini dapat menumbuhkan minat baca pada anak usia dini di SAAJA, Metode yang digunakan adalahMetode StorytellingdanMetode Bermain Sambil Belajar, Hasil kegiatan ini, peserta aktif membaca buku anak-anak selain itu mereka mampu mengasah daya ingat untuk mengingat apa yang telah diceritakan.
\end{abstract}

Kata Kunci : Minat baca, Anak Usia Dini,Storytelling

\section{PENDAHULUAN}

Pendidikan merupakan salah satu hal yang paling penting dalalm suatu bangsa. Dalam pendidikan, seorang anak memerlukan pengajaran yang tepat dalam memenuhi kebutuhan pendidikannya yang disertai dengan pemahaman karakteristik anak sesuai tumbuh kembangnya. Hal ini sangat membantu dalam menyesuaikan proses belajar bagi anak dengan usia, serta kebutuhan dan kondisi masing-masing anak. SAAJA merupakan salah satu pendidikan formal yang ditujukan kepada anak-anak jalanan. SAAJA berada di jalan HR Rasuna Said, Kuningan, Jakarta Selatan. Sekolahan ini didirikan oleh Alm.Farid Faqih pada tahun 2002, dengan tujuan untuk membantu anak-anak jalanan diusia dini yang kurang mendapatkan pendidikan yang layak dengan tidak dipungut biaya apapun.

SAAJA memiliki 3 kelas. Kelas TK A1 setara dengan pendidikan anak usia dini (PAUD), TK A2 untuk anak-anak usia 5-6 tahun, dan TK B untuk anak-anak usia 6-7 tahun. SAAJA memiliki murid sebanyak 44 orang. Dengan proses belajar mengajar yang berlangsung setiap hari senin-jumat pada pukul 10/00 WIB s/d 13.00 WIB dan pada hari sabtu pukul 13.00 WIB s/d 14.00 WIBuntuk tingkat sekolah menengah pertama dan sekolah menegah atas.

Permasalahan yang dihadapi oleh anakanak SAAJA yaitu menurunya minat membaca pada anak-anak tersebut. Apa lagi untuk anak diusia dini seperti mereka, sangat membutuhkan dukungan untuk berkembang. Selain, menurunnya minat baca, di SAAJA minim fasilitas berupa buku bacaan sehingga terbatasnya 
dukungan untuk meningkatkan minat baca di SAAJA.

Menurut Farida Rahim (2005) ada 3 faktor yang mempengaruhi minat baca, pertama faktor fisik yang tidak sehat dapat menyebabkan anak kelelahan. Kelelahan merupakan kondisi yang tidak menguntungkan bagi anak untuk belajar, terutama ketika membaca. Selain itu keterbatasan neurologis, gangguan pendengaran dan penglihatan akan memperlambat anak dalam belajar, terutama ketika membaca. Kedua, faktor intelektual. Secara umum, intelegensi anak tidak sepenuhnya mempengaruhi berhasil atau tidaknya anak dalam membaca, namun dari beberapa penelitian yang salah satunya dilakukan oleh Ehanski (1963) menunjukkan ada hubungan yang positif (tetapi rendah) antara IQ dengan rata-rata remedial membaca. Ketiga, faktor lingkungan juga mempengaruhi kemajuan kemampuan membaca anak. Faktor lingkungan mencakup latar belakang dan pengalaman anak dirumah. Dalam hal ini seorang anak tidak akan mengembangkan minatnya terhadap sesuatu, terutama membaca, jika mereka sebelumnya belum pernah mengalminya. Selain itu faktor ekonomi keluarga juga mempengaruhi minat baca seorang anak terutama dalam penyediaan buku bacaan. Keempat, faktor psikologis meliputi: motivasi, tingkat keterlibatan tekanan, dan kematangan sosio dan emosi (Farida Rahim, 2005).

Pelaksanaan kegiataan ini bertujuan untuk meningkatkan minat baca serta menumbuhkan semangat anak-anak untuk membaca, sehingga mereka mendapatkan pengetahuan yang luas dengan membaca. Kami juga memberikan fasilitas berupa buku dongeng untuk anak-anak seusianya agar mereka pun juga dapat membacanya dirumah.

Tujuan pemberian buku tersebut ditujukan untuk meningkatkan minat baca pada anak usia dini di SAAJA, menurut Farida Rahim dalam Jurnal Pena Indonesia (2005:28) ada beberapa faktor yang mempengaruhi minat serta kemampuan membaca seorang anak sebagai berikut:

\section{Faktor Fisiologis}

Mencakup kesehatan fisik, pertimbangan neurologis, dan jenis kelamin. Kelelahan merupakan kondisi yang tidak menguntungkan bagi anak untuk belajar, terutama ketika membaca. Selain itu keterbatasan neurologis (misalnya berbagai cacat otak), gangguan pendengaran dan penglihatan akan memperlambat anak dalam belajar, terutama ketika membaca.

\section{Faktor Intelektual}

Secara umum, intelegensi anak tidak sepenuhnya mempengaruhi berhasil atau tidaknya anak dalam membaca, namun dari beberapa penelitian yang salah satunya dilakukan oleh Ehanski (1963) menunjukkan ada hubungan yang positif (tetapi rendah) antara IQ dengan rata-rata remedial membaca.

\section{Faktor Lingkungan}

Faktor lingkungan juga mempengaruhi kemajuan kemampuan membaca anak. Faktor lingkungan mencakup latar belakang dan pengalaman anak dirumah. Dalam hal ini seorang anak tidak akan mengembangkan minatnya terhadap sesuatu terutama membaca jika mereka sebelumnya belum pernah mengalminya. Selain itu faktor ekonomi keluarga juga mempengaruhi minat baca seorang anak terutama dalam penyediaan buku bacaan.

4. Faktor Psikologis

\section{a. Motivasi}

Motivasi merupakan faktor kunci dalam membaca. Siswa yang mempunyai motivasi yang tinggi terhadap membaca, akan mempunyai minat yang tinggi pula terhadap kegiatan membaca.

b. Tingkat Keterlibatan Tekanan

Jika siswa merasa dirinya mempunyai beberapa tingkat pilihan dan kurang tekanan, minat membaca mereka mungkin akan lebih tinggi.

c. Kematangan Sosio dan Emosi

Seorang siswa harus mempunyai pengontrolan emosi pada tingkat tertentu. Kematangan sosio dan emosi lebih memudahkan anak dalam memusatkan perhatian pada bahan bacaan sehingga kemampuan anak dalam memahami bacaan akan meningkat.

Menurut Pigaet dalam DR. P. Suparno (2001:19) bahwa belajar akan lebih berhasil apabila disesuaikan dengan tahap perkembangan kognitif peserta didik. Peserta didik hendaknya 
iberi kesempatan untuk melakukan eksperimen dengan obyek fisik, yang ditunjang oleh interaksi dengan dengan teman sebaya dan dibantu oleh pertanyaan-pertanyaan tilikan dari guru. Guru hendaknya banyak memberikan rangsangan kepada peserta didik agar mau berinteraksi dengan lingkungan secara aktif, mencari dan menemukan berbagai hal dari lingkungan.

Implikasi teori perkembangan kognitif Piaget dalam pembelajaran adalah:

1. Bahasa dan cara berpikir anak berbeda dengan orang dewasa. Oleh karena itu, guru mengajar dengan menggunakan bahasa yang sesuai dengan cara berfikir anak.

2. Anak-anak akan belajar lebih baik apabila dapat menghadapi lingkungan dengan baik. Guru harus membantu anak agar dapat berinteraksi dengan lingkungan sebaik-baiknya.

3. Bahan yang harus dipelajari anak hendaknya dirasakan baru tetapi tidak asing.

4. Berikan peluang agar anak dapat belajar sesuai tahap perkembangannya

5. Di dalam kelas, anak-anak hendaknya diberi peluang untuk saling berbicara dan berdiskusi dengan teman-temannya.

Selain Pigaet terdapat teori belajar lain yang dikemukakan oleh Robert Gagne,1968. Ia lahir tahun 1916 di North Andover, Beliau mendapatkan gelar A.B. pada Yale tahun 1937 dan pada tahun 1940 mendapat gelar Ph.D. Ada beberapa hal yang melandasi pandangan Gagne tentang belajar. menurutnya belajar bukan merupakan proses tunggal melainkan proses luas yang dibentuk oleh pertumbuhan dan perkembangan tingkah laku, dimana tingkah laku itu merupakan proses komulatif dari belajar. Artinya banyak keterampilan yang dipelajari memberikan sumbangan bagi belajar keterampilan yang lebih rumit.

Menurut Gagne dalam Dahar, (1991:141143)belajar memberi kontribusi terhadap adaptasi yang diperlukan untuk mengembangkan proses yang logis, sehingga perkembangan tingkah laku (behavior) adalah hasil dari efek belajar yang kumulatif (Gagne, 1968). Lebih lanjut ia menjelaskan bahwa belajar itu bukan proses tunggal. Belajar menurut Gagne tidak dapat didefinisikan dengan mudah, karena belajar bersifat kompleks. Hasil belajar merupakan kapabilitas. Setelah belajar, orang memiliki keterampilan, pengetahuan, sikap dan nilai. Timbulnya kapabilitas tersebut berasal dari

(1) Stimulasi yang berasal dari lingkungan; dan

(2) Proses kognitif yang dilakukan siswa.

Dengan demikian, belajar adalah seperangkat proses kognitif yang mengubah sifat stimulasi lingkungan, melewati pengolahan informasi menjadikan pabilitas baru. Juga dikemukakan bahwa belajar merupakan faktor yang luas yang dibentuk oleh pertumbuhan, perkembangan tingkah laku merupakan hasil dari aspek kumulatif belajar. Berdasarkan pandangan ini Gagne mendefinisikan pengertian belajar secara formal bahwa belajar adalah perubahan dalam disposisi atau kapabilitas manusia yang berlangsung selama satu masa waktu dan tidak semata-mata disebabkan oleh proses pertumbuhan. Perubahan itu berbentuk perubahan tingkah aku. Hal itu dapat diketahui dengan jalan membandingkan tingkah laku sebelum belajar dan tingkah laku yang, diperoleh setelah belajar. Perubahan tingkah laku dapat berbentuk perubahan kapabilitas jenis kerja atau perubahan sikap, minat atau nilai. Perubahan itu harus dapat bertahan selama periode waktu dan dapat dibedakan dengan perubahan karena pertumbuhan, misalnya perubahan tinggi badan atau perkembangan otot dan lain-lain.

Gagne membagi proses belajar berlangsung dalam empat fase utama, yaitu:

1. Fase pengenalan (apprehending phase). Pada fase ini peserta didik memperhatikan stimulus tertentu kemudian menangkap artinya dan memahami stimulus tersebut untuk kemudian ditafsirkan sendiri dengan berbagai cara. Ini berarti bahwa belajar adalah suatu proses yang unik pada tiap siswa, dan sebagai akibatnya setiap siswa bertanggung jawab terhadap belajarnya karena cara yang unik yang dia terima pada situasi belajar.

2. Fase perolehan (acqusition phase). Pada fase ini peserta didik memperoleh pengetahuan baru dengan menghubungkan informasi yang diterima dengan pengetahuan sebelumya. Dengan kata lain pada fase ini siswa membentuk asosiasiasosiasi antara informasi baru dan informasi lama. 
3. Fase penyimpanan (storage phase). Fase storage/retensi adalah fase penyimpanan informasi, ada informasi yang disimpan dalam jangka pendek ada yang dalam jangka panjang, melalui pengulangan informasi dalam memori jangka pendek dapat dipindahkan ke memori jangka panjang.

4. Fase pemanggilan (retrieval phase). Fase Retrieval/Recall, adalah fase mengingat kembali atau memanggil kembali informasi yang ada dalam memori. Kadang-kadang dapat saja informasi itu hilang dalam memori atau kehilangan hubungan dengan memori jangka panjang. Untuk lebih daya ingat maka perlu informasi yang baru dan yang lama disusun secara terorganisasi, diatur dengan baik atas pengelompokan-pengelompokan menjadi katagori, konsep sehingga lebih mudah dipanggil. Kemudian ada fase-fase lain yang dianggap tidak utama, yaitu:

a) Fase motivasi

sebelum pelajaran dimulai guru memberikan motivasi kepada siswa untuk belajar.

b) Fase generalisasi

adalah fase transfer informasi pada situasi-situasi baru, agar lebih meningkatkan daya ingat, siswa dapat diminta mengaplikasikan sesuatu dengan informasi baru tersebut.

c) Fase penampilan

adalah fase dimana siswa harus memperlihatkan sesuatu penampilan yang nampak setelah mempelajari sesuatu.

d) Fase umpan balik

siswa harus diberikan umpan balik dari apa yang telah ditampilkan (reinforcement).

Menurut teori kognitif-sosial Albert Bandura (dalam Firmina Angela Nai,2017:32-35) menyatakan bahwa lingkungan sosial banyak memberi kesempatan bagi individu untuk mendapatkan keterampilan dan kemampuan yang kompleks melalui observasi perilaku model dan konsekuensi behavioral. Perilaku yang diamati merupakan komponen esensial dari belajar.

Teori kognitif-sosial mengidentifikasi beberapa konsekuensi yang mempengaruhi perilaku. Jenis pertama adalah penguatan pengganti atu konsekuensi yang mewakili (vicarious reinforcement, yangs seolah-olah dirasakan sendiri oleh pengamat), diasosiasikan dengan perilaku yang diamati. Model menerima penguatan atau hukuman untuk perilaku tertentu dan konsekuensi untuk model itu yang menimbulkan reaksi emosional pada diri pengamat.

Jenis kedua adalah penguatan langsung, yaitu penguatan positif yang diidentifikasikan dalam pengondisian berpenguat, yaitu perilaku perorangan yang menghasilkan perubahan dalam lingkungan sehingga perilaku itu kemungkinan dilakukan lagi dalam situasi yang sama.

1) Proses internal pembelajar

Empat komponen proses bertanggung jawab atas belajar dan kinerja, yaitu sebagai berikut:

1. Proses atensional (perhatian)

Pengamat memperhatikan dan memahami secara akurat suatu model.

2. Proses retensi (pengingatan)

Proses menangkap, memproses dan menyimpan informasi berupa materi dan contoh model didalam memori, misal guru memperlihatkan bagaimana menulis huruf $\mathrm{A}$, kemudian siswa menirunya dan mencoba menuliskannya sendiri

3. Proses reproduksi motorik

Proses pemilihan dan pengorganisasian respons pada level kognitif, diikuti dengan pelaksanaan.

4. Proses motivasi

Proses memberikan dorongan yang berfungsi sebagai penguatan sehingga siswa termotivasi untuk meniru model. Fase motivasi di kelas dalam model pembelajaran sering berupa pujian atau nilai karena mengimbangi contoh guru.

2) Peran ketangguhan diri

Ketangguhan diri adalah keyakinan seseorang tentang kemampuannya sendiri dan keyakinan ini memotivasi pembelajar dengan cara tertentu.

3) Membimbing proses internal pembelajar

Pembelajara harus memberi kesempatan (a) mengodekan perilaku yang diamati kedalam citra visual atau simbol kata dan (b) secara mental mengulangi perilaku yang dicontohkan:

1.Keterampilan motorik

2.Perilaku konseptual

3.Menfasilitasi ketangguhan pembelajaran

\section{METODE PELAKSANAAN}

Untuk memecahkan masalah dalam hal peningkatkan minat baca di Kalangan Anak Usia Dini di Sekolah Alternatif Anak Jalanan (SAAJA), metode yang dilakukan kepada anak- 
anak adalah metode storytelling dan metode bermain sambil belajar,

Metode storytelling, bertujuan untuk mengasah kreativitas dan imajinasi anak-anak dalam mendengarkan sebuah cerita, oleh karena itu kami menggunakan metode storytelling kepada anak-anak, selain itu kami juga bertanya kepada anak-anak tentang apa yang mereka tangkap dari hasil storytellingtersebut. Metode storytelling ini digunakan untuk menumbuhkan kreativitas anak, menumbuhkan rasa penasaran akan cerita yang disampaikan, sehingga dapat menumbuhkan minat baca dalam diri anak-anak. Kami juga menggunakan metode storytellingdan memanfaatkan media kertas sebagai alat peraga, agar anak-anak tertarik melihat dan mendengarkan sebuah cerita yang disampaikan.

Metode yang kami gunakan adalah metode bermain sambil belajar. Dalam metode ini kami mengajak anak-anak untuk bermain sambil belajar, karna dalam proses belajar pun anak harus merasa senang dan kami ingin menanamkan mindset bahwa belajar itu bukan beban dan membosankan tetapi belajar itu menyenangkan karna bisa bermain. Setelah melakukan storytelling kami mengajak anak-anak untuk merelaksasikan pikiran dengan tarian pinguin. Setelah itu kami memberikan tantangan kepada anak-anak untuk menceritakan kembali apa yang mereka ingat tentang storytelling yang sudah mereka sampaikan atau menceritakan buku tentang apa yang saja yang pernah mereka baca. Hal ini bertujuan agar anak berani membicara didepan banyak orang dan mengasah daya ingat mereka.
Metode ketiga yang kami gunakan adalah Metode pemberian buku dongeng kepada anakanak. Banyak hal yang dapat dilakukan agar anak-anak lebih dekat dengan buku yaitu membuat mereka tertarik untuk membaca dan jika membaca sudah melekat pada keseharian anak-anak, maka langkah selanjutnya yaitu dengan memfasilitasi mereka dengan bahan bacaan yang sesuai dengan usianya.Minat tanpa adanya langkah nyata kurang memberikan hasil yang maksimal.Misalnya semangat untuk membaca dan meminjam buku sudah ada, namun keterbatasan buku bacaan yang membuat mereka semakin tidak tertarik untuk membaca.

\section{HASIL DAN PEMBAHASAN}

Hasil laporan ini dibuat berdasarkan data yang diperoleh selama proses kegiatan PKM "meningkatkan minat baca di kalangan Anak SAAJA" berlangsung. Jumlah anak-anak SAAJA keseluruhan yaitu 44 orang namun ketika PKM berlangsung hanya hadir 36 orang anak di karenakan ada beberapa yang tidak dapat hadir karena sakit. Dari ke 36 anak SAAJA, mempunyai latar belakang kemampuan membaca yang beragam, ada yang agak kurang, kurang, sangat kurang, dan lancar membaca.Contohnya, ketika proses pembagian name tag beberapa anak ingin mengeja namanya sendiri untuk dituliskan di name tag dan ketika penyuluh memberikan kalimat untuk dibaca terdapat beberapa anak yang berani maju ke depan untuk membaca tulisan yang berada di papan tulis.

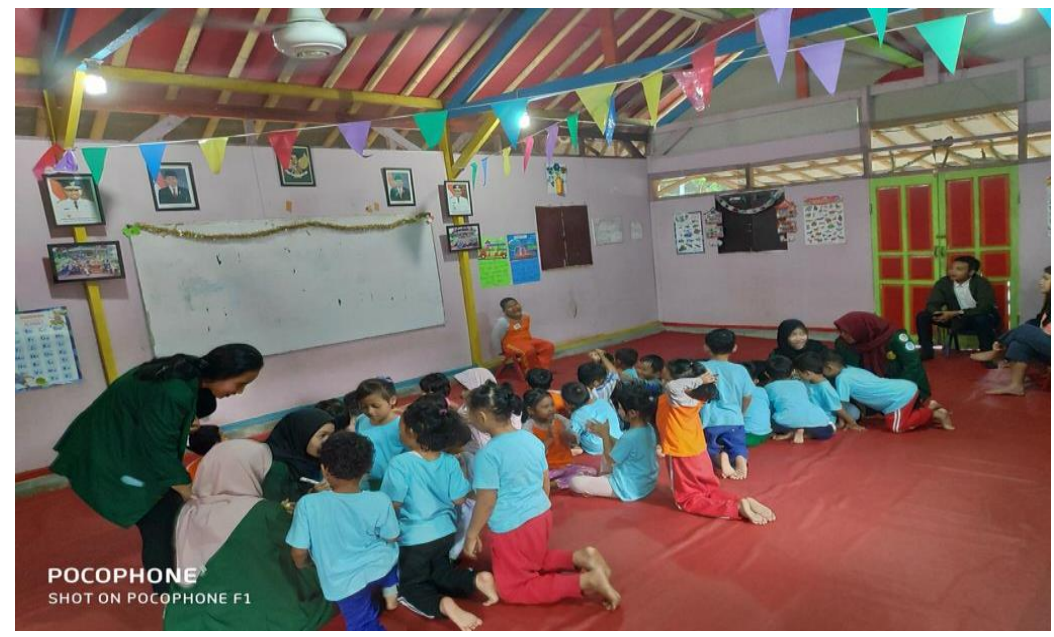

Gambar 1. kegiatan pembagian nametag 
Semangat anak-anak yang belajar di SAAJA sangat tinggi sehingga mereka mengikuti rangkaian kegiatan acara dengan sangat baik salah satunya yaitu mereka melakukan tepuk semangat dan selalu berani menjawab ketika diberi pertanyaan. Meskipun di beberapa waktu terjadi ketidakondusifan dikarenakan terdapat anak yang sangat hiperaktif ketika kegiatan PKM berlangsung. Contohnya yaitu ada anak murid yang berlarian ketika proses belajar berlangsung. Untuk membuat suasana belajar makin menyenangkan kegiatan membaca ini diselingi dengan kegiatan-kegiatan lain berupa kegiatan menari dan bernyanyi bersama, atau informasi aktual lainnya yang bermanfaat untuk diketahui anak-anak SAAJA untuk belajar gemar baca. Kegiatan menari yang dilakukan yaitu senam pinguin dan bernyanyi lagu.
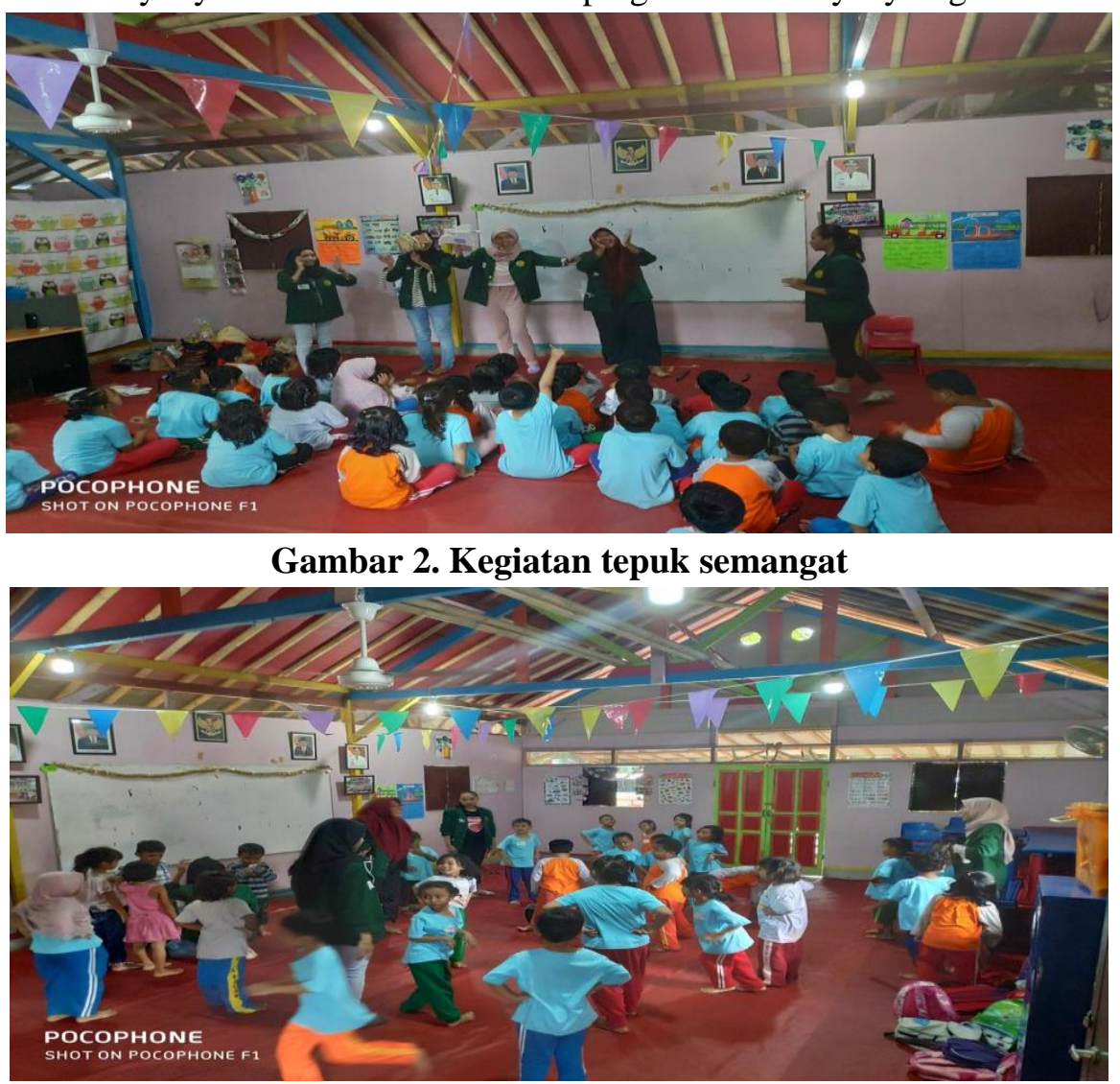

Gambar 3. Kondisi hiperaktif ketika proses belajar berlangsung

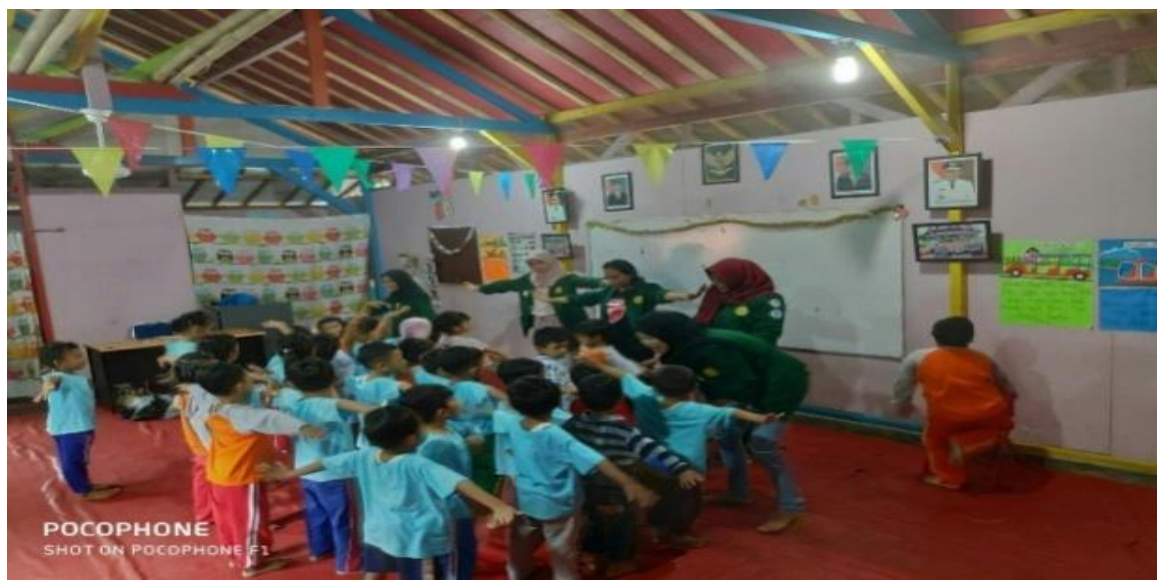

Gambar 4. Kegiatan Menari

Kami memilih Jenis storytelling fabel untuk kami ceritakan kepada anak-anak
SAAJA.Kami memilih tema tentang binatang agar dengan metode ini dapat dengan mudah 
diterima dan dipahami anak-anak karena sesuai dengan jenis usianya.Pertama sebelum kami bercerita kami menayakan kepada anak-anak apakah mereka pernah mengetahuin cerita tentang olli sih burung hantu penakut, ternyata mereka belum pernah menderkannya. Untuk menarik antusias anak-anak untuk mendengarkan cerita kami menunjukan gambar - gambar binatang yang ada di cerita olli sih burung hantu penakut seperti burung hantu, tikus tanah dan kekelawar. Dengan kami menunjukan gambar anak - anak terlihat tertarik untuk mendengarkan cerita dengan baik. Selama kami bercerita di ikuti dengan gambar dan suara hewan yang ada di cerita dan membuat mereka antusias dan senang dalam mendengarkan cerita yang kami sampaikan.

Kami juga menggunakan bahasa yang mudah untuk dipahami oleh anak - anak sehingga mereka paham dengan cerita yang kami ceritakan. Pada akhir cerita kami menayakan kepada anak- anak apa mereka paham tentang cerita yang kami sampaikan anak-anak menjawab mereka paham tentang cerita yang kami sampaikan.Selanjutnya kami juga menjelaskan tentang apa itu hewan nokturnal karena di dalam buku cerita olli sih burung hantu penakut selain menjelaskan bahwa tidak boleh menjadi menjadi orang yang penakut tapi juga mengenalkan kepada anak-anak hewan apa saja yang beraaktifitas pada malam hari kami menjelaskan tentang hewan nokturnal dengan kata- kata yang lebih gampang yang membuat anak- anak menjadi paham. Selesai sesi story tellingkami memberikan pertanyan kepada anak-anak SAAJA untuk mengetahui apa anak-anak SAAJA menyimak cerita yang telah kita bacakan. Kami memberikan pertanyaan tentang apa saja hewan yang ada di dalam cerita olli si burung hantu penakut dan apa saja hal yang tidak boleh di tiru dalah cerita olli si burung hantu penakut. Bagi yang bisa menjawab pertanyaan dengan benar kami memberikan hadiah kepada mereka.

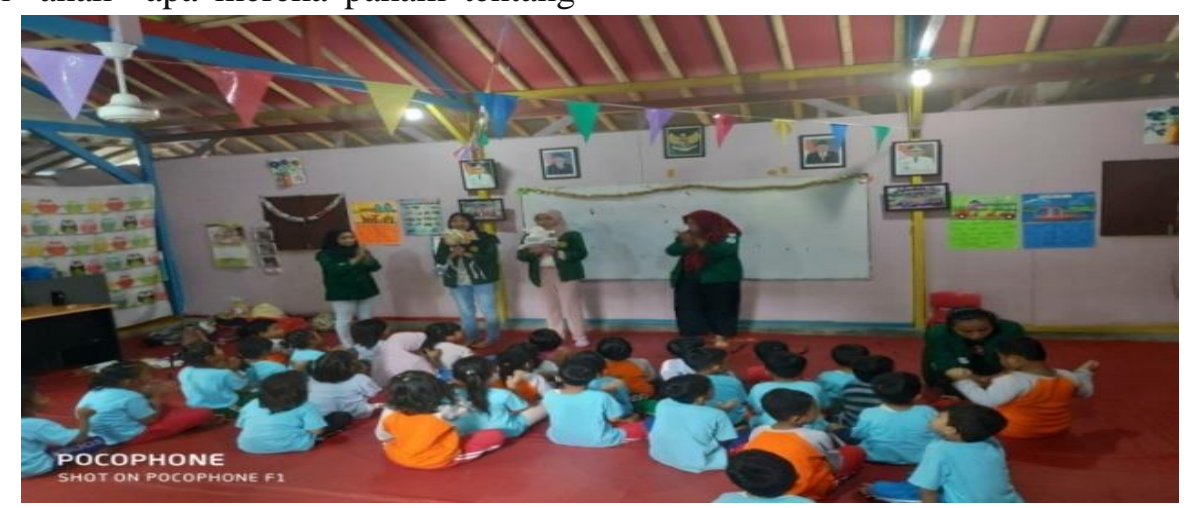

Gambar 5. Kegiatan Storytelling

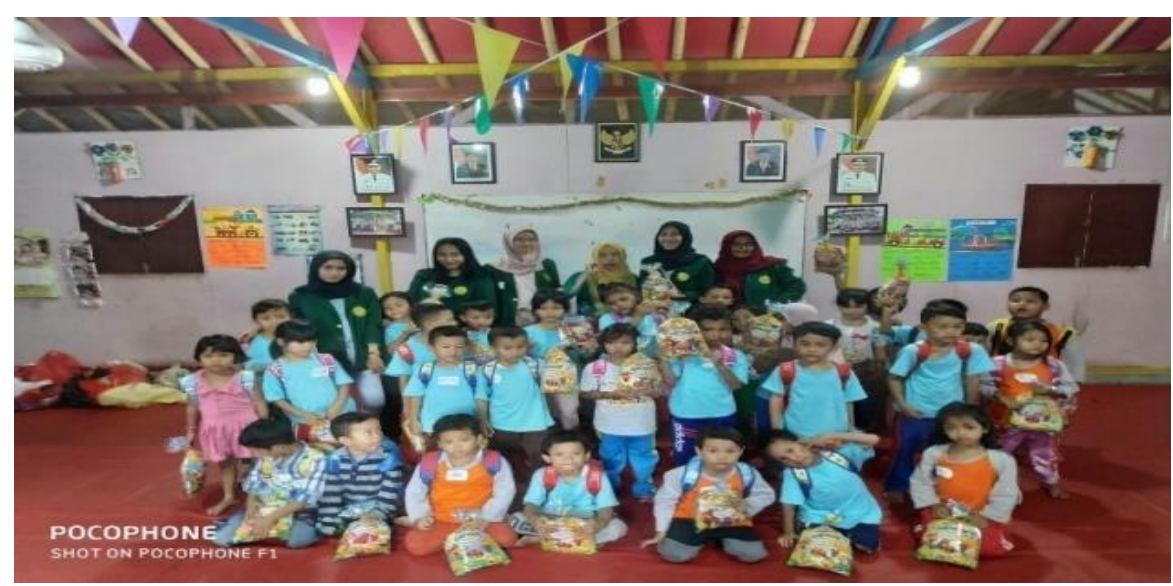

Gambar 6. Pemberian buku bacaan beserta hadiah

\section{SIMPULAN}

Kegiatan pengabdian untuk peningkatan minat baca di kalangan anak usia dini di SAAJA membawa manfaat:
1. Mengasah kreativitas dan imajinasi anakanak dalam mendengarkan sebuah cerita, menumbuhkan rasa penasaran akan cerita yang disampaikan sehingga dapat 
menumbuhkan minat baca dalam diri anak-anak.

2. Membuat anak berani untuk berbicara didepan umum untuk mengungkapkan atau menceritakan kembali apa yang mereka ingat mengenai cerita yang sudah disampaikan.

\section{DAFTAR PUSTAKA}

Angela Nai, Firmina. (2017). Teori Belajardan Implementasinya Dalam Pembelajaran Bahasa Indonesia di SMP, SMA, dan SMK. Yogyakarta: Deepublish

Rahim, Farida. (2008). Pengajaran Membaca di Sekolah Dasar. Jakarta: Bumi Aksara

Piaget, Jean. (1998). Antara Tindakan dan Pikiran. Jakarta: PT. Gramedia

Suparno, Paul. (2001).Teori Perkembangan Kognitif.Yogyakarta: Kanisius 